Original scientific paper - Izvorni znanstveni rad

UDK: 637.146 .21

\title{
Some properties of kefir enriched with apple and lemon fiber
}

doi: $10.15567 /$ mljekarstvo.2017.0305

\author{
Busra Goncu, Asli Celikel, Mutlu B. Guler-Akin*, M. Serdar Akin \\ Harran University Agricultural Faculty, Department of Food Engineering, Şanliurfa, Turkey, 63040 \\ Received - Prispjelo: 07.10.2016. \\ Accepted - Prihvaćeno: 25.05.2017.
}

\begin{abstract}
The effects of apple and lemon fiber addition on some properties of kefir were investigated. Five different kefirs were produced (A is control, B, C, D, E, F and G: contain $0.25 \%$ apple fiber, $0.5 \%$ apple fiber, $1 \%$ apple fiber, $0.25 \%$ lemon fiber, $0.5 \%$ lemon fiber and $1 \%$ lemon fiber, respectively) and stored for 20 days at $4 \pm 1{ }^{\circ} \mathrm{C}$. $\mathrm{pH}$, titratable acidity, dry matter, water activity, water holding capacity, viscosity, L, a and b values, sensorial analysis, total lactic bacteria, Lactococcus spp., Leuconostoc spp. and yeast counts of kefirs were determined at $1^{\text {st }}, 10^{\text {th }}$ and $20^{\text {th }}$ days of storage. The addition of apple and lemon fiber enhanced rheological, microbiological and sensorial properties of kefirs $(\mathrm{p}<0.01)$. Apple and lemon fiber could be used for kefir production at a rate of 0.25 or $0.5 \%$.
\end{abstract}

Key words: kefir, apple fiber, lemon fiber, quality

\section{Introduction}

Kefir is a fermented and carbonated refreshing milk, with a slightly acidic aromatic taste and creamy foam composition which contains yeasts and many bacterial species from genus Lactobacillus, Leuconstoc, Lactococcus and acetic acid bacteria (Chifiriuc et al., 2011). Besides milk ingredients such as proteins, fat and lactose, it also contains small amounts of lactic acid, ethanol, carbon dioxide, acetic acid, acetaldehyde, acetoin and diacetyl, influencing its flavour and odour (Gronnevik et al., 2011; Glibowski and Zielinska, 2015).

The main raw material applied in kefir production is bovine milk; however, kefir can also be produced from caprine or ovine milk (Wszolek et al., 2001; Tratnik et al., 2006; Grzegorczyk and Wszołek, 2010). As well as different kinds of milk, different additives, such as skim milk powder (SMP), whey protein concentrate (Tratnik et al., 2006) and inulin (Tratnik et al., 2006; Ertekin and Guzel-Seydim, 2010; Glibowski and Kowalska, 2012; Montanuci et al., 2012; Glibowski and Zielinska, 2015) were studied for kefir production.
Usually, the addition of the above mentioned substances caused a change of rheological parameters.

Consumers are demanding for foods with increasingly properties, such as pleasant flavor, lowcalorie value or low-fat content and beneficial health effects (Gonzalez-Tomas et al., 2008). Dietary fiber (DF) is a remnant of the edible part of plant; it is analogous carbohydrates that are resistant to digestion and absorption in the human small intestine and undergo complete or partial fermentation in the human large intestine. DF includes oligosaccharides, lignin, resistant starch, tannins and associated plant substances. The significant physicochemical properties of DF include solubility, viscosity, water holding capacity and fermentability (E1leuch et al., 2011; Mudgil and Barak, 2013). DF plays an important role in human health. High DF diets are associated with the prevention, reduction and treatment of some diseases, such as diverticular and coronary heart diseases. This has prompted efforts to add DF into food products (Tungland and Meyer, 2002). Recently, DFs have been commonly used in various food products such as yoghurt, ice cream, beverages, 
pasta, biscuits, and bread (Dello Staffolo et al., 2004; Dervisoglu and Yazici, 2006; Akin, 2005; Akin, Akin and Kirmaci, 2007; Brennan et al., 2008; Sendra et al., 2008; Soukoulis et al., 2009; Gularte et al., 2012; Agama-Acevedo et al., 2012; Paquet et al., 2014; De Lima et al., 2014; $\mathrm{Fu}$ et al., 2015).

The by-products of fruits from industrial applications are potential sources of DF that can be incorporated into food products. The processing of apples, in particular for apple juice, generates the by-product apple pomace, which consists of a heterogeneous mixture of peel, seeds, calyx, stem and pulp. Apple pomace can represent 20-40\% of the weight of processed fruits, depending on the technology used in the extraction of juice (Macagnan et al., 2015). Lemon is the third most important Citrus species in the World and is mainly processed into fruit juice. Lemon pomace accounts for $50-65 \mathrm{~g}$ per $100 \mathrm{~g}$ whole fruit mass, there is a great interest in utilizing the remaining biomass. DF was the major constituents (77.34-81.71\%) in dried lemon by-products (Marin et al., 2007).

Therefore, to use these widely available and low cost fiber sources in human nutrition, elucidating their potential physiological and metabolic actions is fundamental. Thus, it was aimed to develop a functional product containing apple fiber (AF) and lemon fiber (LF). In an attempt to improve the nutritional value of kefir different levels of $\mathrm{AF}$ and LF were added to the batches. Furthermore, the effects of apple and lemon fiber levels on the physicochemical, microbiological and sensory properties of kefir were also examined.

\section{Materials and methods}

\section{Materials}

Cow's milk was supplied from Animal Husbandry unit of the Faculty Agriculture, Harran University. The chemical composition of milk used for the production of kefir fell within the following averages: titratable acidity $0.160 \%( \pm 0.02)$ as lactic acid (L.A.), pH $6.68( \pm 0.015)$, dry matter $11.73 \%( \pm 0.08)$, fat $3.1 \%( \pm 0.03)$, protein $3.35 \%$ $( \pm 0.05)$, lactose $4.58 \%( \pm 0.04)$ and ash $0.75 \%$ $( \pm 0.015)$. Kefir grains were obtained by Professor Celalettin Koçak (Ankara University, Department of Dairy Science and Technology, Ankara, Turkey). Kefir starter culture was prepared by inoculating
$10 \mathrm{~g}$ of kefir grains into $1000 \mathrm{~mL}$ of pasteurized skimmed milk and then incubated at $25{ }^{\circ} \mathrm{C}$ for 22 hours until $\mathrm{pH}$ fell to 4.7. That kefir was used as kefir starter culture, which contains $10.35 \log \mathrm{cfu} / \mathrm{g}$ lactic acid bacteria and lactococci, $7.88 \log \mathrm{cfu} / \mathrm{g}$ Leuconostoc and $6.05 \mathrm{log} \mathrm{cfu} / \mathrm{g}$ yeast.

$\mathrm{AF}$ and LF were obtained from Arosel Food (İstanbul). The gross composition of apple and lemon fiber claimed by the manufacturer is; dietary fiber $70-80 \%$ of which $10 \%$ is soluble, moisture $12 \%$ and fibre $90 \%$, moisture $10 \%$, fat $1 \%$, protein $5 \%$, carbohydrate $1 \%$ and salt $1.3 \%$, respectively. The fibers are $100 \%$ apple fiber and citrus fiber. L, a and b values of AF and LF were 58.61, 8.25, 18.21 and $83.05,0.12$ and 11.56 , respectively. All of the other used reagents were of analytical grade.

\section{Kefir manufacture}

Raw whole cow's milk divided seven parts of $10 \mathrm{~L}$ batches. The first batch was control (A). The other batches supplemented with $0.25,0.5$ and $1 \%$ $\mathrm{AF}$ and LF (B: $0.25 \% \mathrm{AF}, \mathrm{C}: 0.5 \% \mathrm{AF}, \mathrm{D}: 1 \% \mathrm{AF}$, E: $0.25 \% \mathrm{LF}, \mathrm{F}: 0.5 \% \mathrm{LF}$ and G: $1 \% \mathrm{LF}$ ), respectively. Each milk was pasteurized at $90{ }^{\circ} \mathrm{C}$ and kept for 5 min by using a batch type pasteurizer with water jacket vat and cooled to $25^{\circ} \mathrm{C}$ in $2-3 \mathrm{~min}$. The process of the fermentation of milk to be processed was initiated by the addition of kefir starter culture at an amount of $10 \mathrm{~mL} \mathrm{~L}^{-1}$ milk, and incubation was carried out at $25^{\circ} \mathrm{C}$ for 22 hours until $\mathrm{pH}$ reached to 4.7. Then kefir samples were cooled to $4{ }^{\circ} \mathrm{C}$ and stored in glass jars $(1 \mathrm{~L})$ at $4{ }^{\circ} \mathrm{C}$ for 20 days. The experiment was conducted in duplicate (totally 14 kefir samples were analysed).

\section{Chemical analysis}

The $\mathrm{pH}$ of the milk and kefir was measured using a digital $\mathrm{pH}$-meter and titratable acidity was measured by titrating $10 \mathrm{~g}$ of sample with $0.1 \mathrm{~N} \mathrm{NaOH}$ using phenolphthalein indicator (Guler-Akin and Akin 2007). The fat and lactose contents of milk were determined by the Gerber method (T.S.E. 1994) and spectrophotometric (Lawrance, 1968) methods, respectively. The protein, moisture and ash contents of milk were estimated from the crude nitrogen content of the samples determined by the Kjeldahl, oven-drying and gravimetric methods, respectively (AOAC, 1990). The water activity of the kefirs was measured using a water activity meter at $25^{\circ} \mathrm{C}$ (HygroPalmAW1; Rotronic ag, Bassersdorf, Switzerland). 


\section{Physical measurements}

The viscosities of the kefirs were determined at $4{ }^{\circ} \mathrm{C}$ using a digital Brookfield Viscometer, Model DV-II (Brookfield Engineering Laboratories, Stoughton, MA, USA) (Akin et al., 2007).

Water-holding capacity of kefir was determined using a centrifuge (Mudgil et al., 2016). $10 \mathrm{~g}$ of kefir (X) sample was centrifuged at $3000 \mathrm{rpm}$ for $20 \mathrm{~min}$ at $4{ }^{\circ} \mathrm{C}$. The whey (Y) separated was removed and weighed. The water-holding capacity was calculated as.

Water Holding Capacity $(\%)=[(\mathrm{X}-\mathrm{Y}) / \mathrm{X}] \mathrm{x} 100)$

\section{Color measurements}

A reflectance colorimeter (Color Quest XE, USA) was used to determine Hunter $L, a$ and $b$ color parameters of the kefir samples. The source of light and the observation angle are D65 and $10^{\circ}$.

\section{Microbiological enumerations}

Kefir samples (10 g) were decimally diluted in $100 \mathrm{~mL}$ sterile peptone water $(0.1 \%)$ and $1 \mathrm{~mL}$ aliquot dilutions were poured onto plates in triplicate. Lactococcus spp. counts were determined in M17lactose agar (Difco ${ }^{\circledR}$ ), followed by incubation under aerobic condition at $30^{\circ} \mathrm{C}$ for 48 hours (Garcia Fontan et al., 2006). Leuconostoc spp. counts were determined on APT agar $\left(\right.$ Merck $\left.^{\circledR}\right)$ supplemented with sucrose $\left(100 \mathrm{~g} \mathrm{~L}^{-1}\right)$ and $0.005 \%$ of sodium azide, and it was incubated under aerobic condition at $22{ }^{\circ} \mathrm{C}$ for 4 days (Montanuci et al., 2012). Total lactic acid bacteria (LAB) were enumerated on MRS agar $\left(\right.$ Merck $\left.^{\circledR}\right)$ and incubated under aerobic condition at $30{ }^{\circ} \mathrm{C}$ for 48 hours (Garrote; Abraham; De Antoni, 2001).

Yeast count was determined on YGC agar (yeast extract glucose chloramphenicol agar). The medium was acidified to $\mathrm{pH} 3.5$ by adding a sterile (Millipore $0.45 \mu \mathrm{m}$ membrane filter) $10 \%$ tartaric acid (w/v) solution. Incubation was performed aerobically at $25^{\circ} \mathrm{C}$ for 5 days (Montanuci et al., 2012).

\section{Sensory evaluation}

The samples were organoleptically assessed by untrained ten panelists using a 10 point hedonic scale as described by Bodyfelt et al. (1988). The properties evaluated included flavour and taste, consistency and general acceptability ( 1 = strongly unacceptable, 10 = very good). The panel of assessors was an external panel (consisted of staff from the Harran University Department of Food Engineering, Turkey) of non-smokers who were very familiar with dairy products and were checked on the basis of sensory acuity and consistency.

\section{Statistical analysis}

Statistical analysis of data via one-way analysis of variance (ANOVA) was performed to check the significance of differences at $\mathrm{p}<0.01$ using SPSS Version5.0 (SPSS Inc. Chicago, IL, USA). Statistically different groups were determined by the LSD (Least Significant Difference) test (Düzgünes et al., 1987).

\section{Result and discussions}

\section{Physicochemical properties}

The effect of fiber type and fiber level on the $\mathrm{pH}$, titratable acidity and dry matter of kefir was significant $(p<0.01)$ (Table 1). Control sample had the lowest dry matter content because it had not been fortified with DF. There are no differences statistically between the samples AF and LF according to their dry matter. The dry matter of kefirs slightly increased as the DF content increased. Storage did not affect the dry matter content of the samples $(\mathrm{p}>0.05)$.

The $\mathrm{pH}$ of the samples was ranged between 4.26 and 4.65. Addition of DF caused to the decrease of $\mathrm{pH}$ values and increase of the acidity and dry matter content of kefirs. The results indicate that $\mathrm{AF}$ added kefir samples had the lowest $\mathrm{pH}$ and the highest acidity contents. We concluded that AF had more improvement effect on the lactic acid bacteria than LF. $\mathrm{pH}$ decreased and the acidity increased as the fiber rate increased up to at a rate of $0.5 \%$. It could be related to stimulation of lactic acid bacteria by fiber. Previous studies have also demonstrated that kefir as a probiotic (Van Wyk, 2001; Chifiriuc et al., 2011) and dietary fiber had a potential prebiotic effect (Ferliarslan, 2012; Guzeler et al., 2010). However, addition of $1 \%$ fiber increased the $\mathrm{pH}$ values and decreased the acidity content of all samples. The result of that study could be related to lower water activity $\left(\mathrm{a}_{\mathrm{w}}\right)$ of kefir samples enriched with $1 \%$ 
AF and LF. As known, DF had very high water holding capacity (Figuerola et al., 2005; Macagnan et al., 2015). So the lactic acid bacteria couldn't find enough water for growing or producing lactic acid. Lactic acid bacteria in kefir culture need 0.95-1 water activity (Ayhan, 2000). $\mathrm{A}_{\mathrm{w}}$ of kefir samples supplied with $1 \%$ DF was under 0.95 (Table 1). As expected, the storage time significantly affected the level of acidity in the samples $(\mathrm{p}<0.01)$, titratable acidity contents increased, while the $\mathrm{pH}$ decreased due to the catabolism of lactose. Glibowski and Zielinska (2015) reported that $\mathrm{pH}$ of kefirs decreased during storage. However, Gronnevik et al. (2011) noticed substantial decrease in $\mathrm{pH}$ values of kefirs during the first week with no further changes for the next 3 weeks of storage.
The water activity values of kefir samples were between 0.93-0.99. Control samples had the highest $a_{w}$. Addition of DF reduced $a_{w}$ of kefirs due to the being highly hygroscopic and water binding capacity of DF. According to our result binding water of AF is slightly higher than the LF. Fiber concentration affected $a_{w}$ negatively $(p<0.01)$. The result of this is that the water molecules become immobilized and unable to move freely among other molecules of the kefirs enriched with DF. Storage did not affect $a_{w}$ of the samples $(\mathrm{p}>0.05)$.

The viscosity of the kefir samples fortified with DF was higher than control sample. The increased viscosity of the fiber-enriched kefir seems to be caused both by the contribution of the soluble matter to the composition of the aqueous phase and by

Table 1. Physicochemical properties of kefir samples $(n=2)$

\begin{tabular}{|c|c|c|c|c|c|c|c|}
\hline Sample & $\begin{array}{l}\text { Storage } \\
\text { period } \\
\text { (day) }\end{array}$ & $\begin{array}{l}\text { Dry matter } \\
(\%)\end{array}$ & $\mathrm{pH}$ & $\begin{array}{c}\text { Titratable } \\
\text { acidity (\%L.A.) }\end{array}$ & $\begin{array}{l}\text { Water } \\
\text { activity }\end{array}$ & $\begin{array}{l}\text { Viscosity } \\
\text { (mPa.s) }\end{array}$ & $\begin{array}{c}\text { Water holding } \\
\text { capacity } \\
(\%)\end{array}$ \\
\hline \multirow{3}{*}{ Control } & 1. & $12.34 \pm 0.23^{\mathrm{d}}$ & $4.65 \pm 0.02^{\mathrm{al}}$ & $0.68 \pm 0.009^{\mathrm{k} 3}$ & $0.99 \pm 0.01^{\mathrm{a}}$ & $0.673 \pm 0.01^{\mathrm{h} 2}$ & $35.73 \pm 0.32^{\mathrm{n} 3}$ \\
\hline & 10. & $12.36 \pm 0.06^{\mathrm{d}}$ & $4.56 \pm 0.0 \mathrm{l}^{\mathrm{c} 2}$ & $0.78 \pm 0.01^{\mathrm{h} 2}$ & $0.99 \pm 0.005^{\mathrm{a}}$ & $0.794 \pm 0.01^{\mathrm{gl}}$ & $37.37 \pm 0.77^{\mathrm{m} 2}$ \\
\hline & 20. & $12.33 \pm 0.3^{\mathrm{d}}$ & $4.48 \pm 0.0 \mathrm{l}^{\mathrm{d} 3}$ & $0.87 \pm 0.006^{g 1}$ & $0.99 \pm 0.0^{\mathrm{a}}$ & $0.807 \pm 0.01^{\mathrm{g} 1}$ & $38.46 \pm 1.24^{11}$ \\
\hline \multirow{3}{*}{$0.25 \% \mathrm{AF}$} & 1. & $12.61 \pm 0.07^{\mathrm{c}}$ & $4.61 \pm 0.01^{\mathrm{bl}}$ & $0.76 \pm 0.013^{\mathrm{i} 3}$ & $0.96 \pm 0.01^{\mathrm{d}}$ & $0.990 \pm 0.01^{\mathrm{e} 3}$ & $41.56 \pm 0.32^{\mathrm{k} 3}$ \\
\hline & 10. & $12.62 \pm 0.31^{\mathrm{c}}$ & $4.38 \pm 0.06^{\mathrm{f2}}$ & $0.96 \pm 0.028^{\mathrm{e} 2}$ & $0.96 \pm 0.005^{\mathrm{d}}$ & $1.295 \pm 0.02^{\mathrm{c} 2}$ & $46.57 \pm 0.44^{\mathrm{i} 2}$ \\
\hline & 20. & $12.65 \pm 0.03^{c}$ & $4.29 \pm 0.01^{\mathrm{g}^{3}}$ & $1.21 \pm 0.004^{\mathrm{bl}}$ & $0.96 \pm 0.003^{d}$ & $1.400 \pm 0.01^{\mathrm{bl}}$ & $49.20 \pm 0.52^{g 1}$ \\
\hline \multirow{3}{*}{$0.5 \% \mathrm{AF}$} & 1. & $12.84 \pm 0.12^{b}$ & $4.60 \pm 0.02^{\mathrm{bl}}$ & $0.78 \pm 0.02^{\mathrm{h} 3}$ & $0.95 \pm 0.001^{\mathrm{e}}$ & $1.025 \pm 0.03^{\mathrm{e} 3}$ & $43.23 \pm 0.93^{j 3}$ \\
\hline & 10. & $12.86 \pm 0.06^{\mathrm{b}}$ & $4.36 \pm 0.06^{\mathrm{f2}}$ & $0.98 \pm 0.02^{\mathrm{e}^{2}}$ & $0.95 \pm 0.002^{\mathrm{e}}$ & $1.330 \pm 0.05^{c^{2}}$ & $50.47 \pm 1.53^{\mathrm{f} 2}$ \\
\hline & 20. & $12.85 \pm 0.1^{\mathrm{b}}$ & $4.26 \pm 0.04^{\mathrm{h} 3}$ & $1.29 \pm 0.09^{\mathrm{al}}$ & $0.95 \pm 0.01^{\mathrm{e}}$ & $1.432 \pm 0.01^{\mathrm{al}}$ & $55.15 \pm 0.36^{\mathrm{d} 1}$ \\
\hline \multirow{3}{*}{$1 \% \mathrm{AF}$} & 1. & $13.10 \pm 0.15^{a}$ & $4.63 \pm 0.01^{\mathrm{al}}$ & $0.72 \pm 0.004^{33}$ & $0.93 \pm 0.002^{g}$ & $1.054 \pm 0.01^{\mathrm{e} 3}$ & $48.54 \pm 0.38^{\mathrm{g} 3}$ \\
\hline & 10. & $13.11 \pm 0.04^{\mathrm{a}}$ & $4.48 \pm 0.01^{\mathrm{d} 2}$ & $0.86 \pm 0.013^{g^{2}}$ & $0.93 \pm 0.003^{g}$ & $1.380 \pm 0.03^{\mathrm{b} 2}$ & $56.83 \pm 0.39^{c 2}$ \\
\hline & 20. & $13.12 \pm 0.14^{\mathrm{a}}$ & $4.35 \pm 0.02^{\mathrm{f3}}$ & $1.10 \pm 0.006^{\mathrm{dl}}$ & $0.93 \pm 0.009 \mathrm{~g}$ & $1.471 \pm 0.01^{\mathrm{al}}$ & $60.47 \pm 0.39^{\mathrm{al}}$ \\
\hline \multirow{3}{*}{$0.25 \% \mathrm{LF}$} & 1. & $12.57 \pm 0.16^{c}$ & $4.61 \pm 0^{\mathrm{bl}}$ & $0.76 \pm 0.035^{i 3}$ & $0.98 \pm 0.004^{b}$ & $9.73 \pm 0.02^{+3}$ & $40.74 \pm 0.33^{k 3}$ \\
\hline & 10. & $12.55 \pm 0.04^{\mathrm{c}}$ & $4.45 \pm 0.01^{\mathrm{e} 2}$ & $0.92 \pm 0.007^{\mathrm{f} 2}$ & $0.98 \pm 0.004^{b}$ & $1.241 \pm 0.03^{\mathrm{d} 2}$ & $45.95 \pm 0.23^{\mathrm{i} 2}$ \\
\hline & 20. & $12.58 \pm 0.22^{c}$ & $4.32 \pm 0.01^{g^{3}}$ & $1.15 \pm 0.007^{\mathrm{cl}}$ & $0.98 \pm 0.005^{b}$ & $1.374 \pm 0.03^{\mathrm{bl}}$ & $48.11 \pm 0.40^{\mathrm{hl}}$ \\
\hline \multirow{3}{*}{$0.5 \% \mathrm{LF}$} & 1. & $12.85 \pm 0.21^{b}$ & $4.60 \pm 0.03^{\mathrm{b} 1}$ & $0.80 \pm 0.05^{\mathrm{h} 3}$ & $0.97 \pm 0.003^{c}$ & $1.018 \pm 0.04^{\mathrm{e} 3}$ & $42.84 \pm 0.27^{j^{3}}$ \\
\hline & 10. & $12.85 \pm 0.11^{\mathrm{b}}$ & $4.43 \pm 0.04^{\mathrm{e}^{2}}$ & $0.90 \pm 0.02^{f 2}$ & $0.97 \pm 0.005^{c}$ & $1.300 \pm 0.15^{c 2}$ & $49.80 \pm 0.15^{\mathrm{f} 2}$ \\
\hline & 20. & $12.84 \pm 0.03^{\mathrm{b}}$ & $4.29 \pm 0.04^{\mathrm{g}^{3}}$ & $1.19 \pm 0.04^{\mathrm{bl}}$ & $0.97 \pm 0.001^{c}$ & $1.403 \pm 0.20^{\mathrm{bl}}$ & $54.29 \pm 0.29^{\mathrm{el}}$ \\
\hline \multirow{3}{*}{$1 \% \mathrm{LF}$} & 1. & $13.12 \pm 0.12^{\mathrm{a}}$ & $4.64 \pm 0.0^{\mathrm{a} 1}$ & $0.70 \pm 0.002^{\mathrm{j} 3}$ & $0.94 \pm 0.005^{f}$ & $1.027 \pm 0.02^{\mathrm{e} 3}$ & $46.52 \pm 0.4^{i 3}$ \\
\hline & 10. & $13.11 \pm 0.2^{\mathrm{a}}$ & $4.49 \pm 0.01^{\mathrm{d} 2}$ & $0.85 \pm 0.013^{\mathrm{g}^{2}}$ & $0.94 \pm 0.008^{f}$ & $1.352 \pm 0.03^{\mathrm{b} 2}$ & $54.27 \pm 0.39^{\mathrm{e} 2}$ \\
\hline & 20. & $13.14 \pm 0.09^{\mathrm{a}}$ & $4.36 \pm 0.02^{\mathrm{f3}}$ & $1.08 \pm 0.022^{\mathrm{dl}}$ & $0.94 \pm 0.007^{\mathrm{f}}$ & $1.435 \pm 0.03^{\mathrm{al}}$ & $58.46 \pm 0.44^{\mathrm{bl}}$ \\
\hline
\end{tabular}

${ }^{a-c / 1-3}$ Means in the same column followed by different letters were significantly different according to fiber and different numbers were significantly different according to storage period $(\mathrm{p}<0.01)$.

AF: Apple fiber, LF: Lemon fiber 
the contribution of insoluble fibers to the increase of total solids (Soukolis et al., 2009), affecting the three dimensional conformation of the hydrated biopolymers. However, Ertekin and Guzel-Seydim (2010) and Glibowski and Zielinska (2015) reported that addition of inulin, which is soluble fiber, reduced the viscosity of kefir. The samples enriched with AF had the highest viscosity value. It could be related the higher soluble and insoluble fiber and pectin content of AF. The significant content of soluble matter in pectin of $\mathrm{AF}$, which is well known for its gel-forming ability (Macagnan et al., 2015), can explain the intense enhancement of viscosity, greater than the other samples. Viscosity values significantly increased with increasing the fiber levels. This can be explained by the interactions of the DF and liquid components of kefir. DF, being highly hygroscopic, would bind water (Elleuch et al., 2011; Mudgil and Barak, 2013).

Table 2. Color properties of kefir samples $(n=2)$
Water holding capacity of a product, such as yoghurt or kefir, is its tendency to retain water or its resistance towards phase separation of the product. The kefirs made with DF showed a significantly higher level water holding capacity $(\mathrm{p}<0.01)$ than control. It could be related to the synergistic effect of both soluble and insoluble fibers. Fiber may act as a stabilizer due to its capacity for binding water (Elleuch et al., 2011; Mudgil and Barak, 2013). The samples enriched with AF had slightly higher water holding capacity than the sample supplied with LF, due to the probably higher water holding capacity of AF. Macagnan et al (2015) determined that the faeces moisture content of rats feed with apple pomace was higher than the faeces moisture content of rats feed with orange bassage. Water holding capacity of kefirs increased as the fiber rate increased $(\mathrm{p}<0.05)$. Viscosity and water holding capacity of kefirs increased continuously throughout storage period in a similar way for all the samples $(\mathrm{p}<0.01)$.

\begin{tabular}{|c|c|c|c|c|c|}
\hline Sample & $\begin{array}{l}\text { Storage period } \\
\text { (day) }\end{array}$ & $\mathrm{L}$ & a & $\mathrm{b}$ & $\mathrm{C}$ \\
\hline \multirow{3}{*}{ Control } & 1. & $78.87 \pm 0.37^{a}$ & $-1.53 \pm 0.05^{\mathrm{g} 1}$ & $9.17 \pm 0.01^{\mathrm{h} 3}$ & $7.64 \pm 0.06^{\mathrm{h}}$ \\
\hline & 10. & $78.85 \pm 0.15^{\mathrm{a}}$ & $-1.52 \pm 0.02^{g}$ & $9.21 \pm 0.0^{\mathrm{h}}$ & $7.69 \pm 0.02^{g}$ \\
\hline & 20. & $78.86 \pm 0.1^{\mathrm{a}}$ & $-1.55 \pm 0.05^{\mathrm{g}}$ & $9.19 \pm 0.01^{\mathrm{h}}$ & $7.64 \pm 0.04^{\mathrm{h}}$ \\
\hline \multirow{3}{*}{$0.25 \% \mathrm{AF}$} & 1. & $71.93 \pm 0.21^{\mathrm{e}}$ & $0.49 \pm 0.02^{c}$ & $10.58 \pm 0.02^{\mathrm{f}}$ & $11.07 \pm 0.0^{c}$ \\
\hline & 10. & $71.91 \pm 0.43^{\mathrm{e}}$ & $0.50 \pm 0.01^{\mathrm{c}}$ & $10.59 \pm 0.0^{\mathrm{f}}$ & $11.09 \pm 0.01^{\mathrm{c}}$ \\
\hline & 20. & $71.89 \pm 0.09^{e}$ & $0.50 \pm 0.02^{\mathrm{c}}$ & $10.58 \pm 0.01^{\mathrm{f}}$ & $11.08 \pm 0.01^{\mathrm{c}}$ \\
\hline \multirow{3}{*}{$0.5 \% \mathrm{AF}$} & 1. & $70.16 \pm 0.31^{f}$ & $0.79 \pm 0.01^{b}$ & $10.59 \pm 0.0^{f}$ & $11.38 \pm 0.01^{b}$ \\
\hline & 10. & $70.09 \pm 0.09^{f}$ & $0.80 \pm 0.02^{\mathrm{b}}$ & $10.59 \pm 0.01^{\mathrm{f}}$ & $11.39 \pm 0.01^{\mathrm{b}}$ \\
\hline & 20. & $70.11 \pm 0.15^{\mathrm{f}}$ & $0.80 \pm 0.01^{\mathrm{b}}$ & $10.57 \pm 0.0^{\mathrm{f}}$ & $11.37 \pm 0.01^{\mathrm{b}}$ \\
\hline \multirow{3}{*}{$1 \% \mathrm{AF}$} & 1. & $67.25 \pm 0.44^{\mathrm{g}}$ & $1.44 \pm 0.06^{\mathrm{a}}$ & $10.60 \pm 0.01^{\mathrm{e}}$ & $12.04 \pm 0.07^{\mathrm{a}}$ \\
\hline & 10. & $67.23 \pm 0.23^{g}$ & $1.46 \pm 0.0^{\mathrm{a}}$ & $10.60 \pm 0.0^{\mathrm{e}}$ & $12.06 \pm 0.0^{\mathrm{a}}$ \\
\hline & 20. & $67.23 \pm 0.11^{\mathrm{g}}$ & $1.45 \pm 0.01^{\mathrm{a}}$ & $10.61 \pm 0.02^{\mathrm{e}}$ & $12.06 \pm 0.03^{\mathrm{a}}$ \\
\hline \multirow{3}{*}{$0.25 \% \mathrm{LF}$} & 1. & $77.87 \pm 0.14^{b}$ & $-0.88 \pm 0.03^{f}$ & $11.30 \pm 0.01^{\mathrm{d}}$ & $10.42 \pm 0.02^{\mathrm{f}}$ \\
\hline & 10. & $77.89 \pm 0.35^{\mathrm{b}}$ & $-0.89 \pm 0.02^{\mathrm{f}}$ & $11.31 \pm 0.01^{\mathrm{d}}$ & $10.42 \pm 0.03^{f}$ \\
\hline & 20. & $77.87 \pm 0.19^{\mathrm{b}}$ & $-0.89 \pm 0.0^{f}$ & $11.30 \pm 0.0^{\mathrm{d}}$ & $10.41 \pm 0.0^{f}$ \\
\hline \multirow{3}{*}{$0.5 \% \mathrm{LF}$} & 1. & $76.24 \pm 0.21^{\mathrm{c}}$ & $-0.80 \pm 0.01^{\mathrm{e}}$ & $11.45 \pm 0.01^{\mathrm{c}}$ & $10.65 \pm 0.0^{\mathrm{e}}$ \\
\hline & 10. & $76.25 \pm 0.14^{c}$ & $-0.81 \pm 0.01^{\mathrm{e}}$ & $11.45 \pm 0.02^{\mathrm{c}}$ & $10.64 \pm 0.01^{\mathrm{e}}$ \\
\hline & 20. & $76.24 \pm 0.37^{c}$ & $-0.80 \pm 0.0^{\mathrm{e}}$ & $11.44 \pm 0.0^{c}$ & $10.64 \pm 0.0^{\mathrm{e}}$ \\
\hline \multirow{3}{*}{$1 \% \mathrm{LF}$} & 1. & $75.26 \pm 0.18^{d}$ & $-0.72 \pm 0.01^{d}$ & $11.61 \pm 0.01^{\mathrm{a}}$ & $10.89 \pm 0.02^{\mathrm{d}}$ \\
\hline & 10. & $75.25 \pm 0.03^{\mathrm{d}}$ & $-0.73 \pm 0.0^{\mathrm{d}}$ & $11.62 \pm 0.0^{\mathrm{a}}$ & $10.89 \pm 0.0^{\mathrm{d}}$ \\
\hline & 20. & $75.25 \pm 0.1^{\mathrm{d}}$ & $-0.72 \pm 0.01^{\mathrm{d}}$ & $11.60 \pm 0.02^{\mathrm{a}}$ & $10.88 \pm 0.01^{\mathrm{d}}$ \\
\hline
\end{tabular}

${ }^{a-c}$ Means in the same column followed by different letters were significantly different $(\mathrm{p}<0.01)$

AF: Apple fiber, LF: Lemon fiber 


\section{Color properties}

The fiber type and level significantly affected the $\mathrm{L}, \mathrm{a}, \mathrm{b}$ and $\mathrm{C}$ values of kefirs $(\mathrm{p}<0.01)$. Lightness $(L)$ values of kefir samples were closer but with AF were significantly lower than the other samples (Table 2). All samples except AF had negative $a$ (greenness) values. The lowest $b$ value was obtained in control samples whereas the highest was obtained in LF added samples. The samples fortified AF had the lowest $\mathrm{C}$ values and followed by LF and control samples, respectively. The increase in the concentration of fiber diminished to lightness, contributed to the red color, yellow color and $\mathrm{C}$ values of the samples. $\mathrm{L}, \mathrm{a}, \mathrm{b}$ and $\mathrm{C}$ values didn't change during storage $(p>0.05)$.

\section{Microbiological counts}

Lactic acid bacteria (LAB) counts were between 9.79-10.89 log cfu mL-1 during storage time (Table 3). The number of LAB were found to be higher in the DF added samples than the control samples $(p<0.01)$. This could be due to the stimulated growth of lactic acid bacteria by DF. The effects of fiber type on the lactic acid bacteria counts of kefir were negligible $(p>0.05)$. However, the samples enriched with AF had slightly higher bacterial counts than the samples enriched with LF. Bacterial counts of kefir increased slowly up to at a rate of $0.5 \% \mathrm{DF}$ addition, and decreased at a rate of $1 \% \mathrm{DF}$ addition. The result of this could be attributed to lower water activity $\left(a_{w}\right)$ of kefir samples enriched with $1 \%$ DF. About a 0.5 log cycle reduction was observed during the storage.

Table 3. Microbiological contents of kefir samples $(\log \mathrm{cfu} / \mathrm{mL})(\mathrm{n}=2)$

\begin{tabular}{|c|c|c|c|c|c|}
\hline Samples & $\begin{array}{l}\text { Storage period } \\
\text { (day) }\end{array}$ & $\begin{array}{l}\text { Lactic acid bacteria } \\
\text { counts }\end{array}$ & $\begin{array}{l}\text { Lactococcus spp. } \\
\text { counts }\end{array}$ & $\begin{array}{l}\text { Leuconostoc spp. } \\
\text { counts }\end{array}$ & Yeast counts \\
\hline \multirow{3}{*}{ Control } & 1. & $10.23 \pm 0.41^{\mathrm{cl}}$ & $10.53 \pm 0.96^{1}$ & $7.78 \pm 0.28^{c 2}$ & $6.09 \pm 0.0^{c 2}$ \\
\hline & 10. & $9.97 \pm 0.57^{c 2}$ & $10.19 \pm 0.62^{2}$ & $8.14 \pm 0.38^{\mathrm{bl}}$ & $7.39 \pm 51^{\mathrm{al}}$ \\
\hline & 20. & $9.61 \pm 0.84^{c^{2}}$ & $9.79 \pm 0.53^{3}$ & $8.35 \pm 0.71^{\mathrm{al}}$ & $7.59 \pm 0.24^{\mathrm{al}}$ \\
\hline \multirow{3}{*}{$0.25 \% \mathrm{AF}$} & 1. & $11.15 \pm 0.88^{\mathrm{al}}$ & $10.78 \pm 0.49^{1}$ & $7.80 \pm 0.66^{c 2}$ & $6.02 \pm 0.37^{\mathrm{c} 2}$ \\
\hline & 10. & $10.71 \pm 0.92^{\mathrm{b} 2}$ & $10.36 \pm 0.62^{2}$ & $8.17 \pm 0.44^{\mathrm{bl}}$ & $7.35 \pm 0.80^{\mathrm{bl}}$ \\
\hline & 20. & $10.67 \pm 0.56^{\mathrm{b} 2}$ & $9.88 \pm 0.87^{3}$ & $8.38 \pm 0.59^{\mathrm{al}}$ & $7.60 \pm 0.61^{\mathrm{al}}$ \\
\hline \multirow{3}{*}{$0.5 \% \mathrm{AF}$} & 1. & $11.25 \pm 0.77^{\mathrm{al}}$ & $10.89 \pm 0.99^{1}$ & $7.79 \pm 0.61^{c^{3}}$ & $6.12 \pm 0.29^{c 2}$ \\
\hline & 10. & $10.99 \pm 0.45^{\mathrm{a} 2}$ & $10.31 \pm 0.58^{2}$ & $8.13 \pm 0.28^{\mathrm{b} 2}$ & $7.39 \pm 0.86^{\mathrm{al}}$ \\
\hline & 20. & $10.73 \pm 0.63^{\mathrm{b} 2}$ & $9.95 \pm 0.77^{3}$ & $8.41 \pm 0.18^{\mathrm{al}}$ & $7.63 \pm 0.44^{\mathrm{al}}$ \\
\hline \multirow{3}{*}{$1 \% \mathrm{AF}$} & 1. & $11.00 \pm 0.84^{\mathrm{al}}$ & $10.60 \pm 0.86^{1}$ & $7.81 \pm 0.36^{c 3}$ & $6.01 \pm 0.78^{\mathrm{c} 2}$ \\
\hline & 10. & $10.58 \pm 0.96^{\mathrm{b} 2}$ & $10.19 \pm 0.79^{2}$ & $8.13 \pm 0.49^{\mathrm{b} 2}$ & $7.37 \pm 0.69^{\mathrm{al}}$ \\
\hline & 20. & $10.49 \pm 0.39^{\mathrm{b} 2}$ & $9.81 \pm 0.63^{3}$ & $8.35 \pm 0.72^{\mathrm{al}}$ & $7.53 \pm 0.77^{\mathrm{al}}$ \\
\hline \multirow{3}{*}{$0.25 \% \mathrm{LF}$} & 1. & $11.03 \pm 0.87^{\mathrm{al}}$ & $10.66 \pm 0.35^{1}$ & $7.78 \pm 0.82^{\mathrm{c} 3}$ & $6.10 \pm 0.41^{c 3}$ \\
\hline & 10. & $10.59 \pm 0.94^{\mathrm{b} 2}$ & $10.33 \pm 0.29^{2}$ & $8.15 \pm 0.59^{\mathrm{b} 2}$ & $7.36 \pm 0.50^{\mathrm{a} 2}$ \\
\hline & 20. & $10.46 \pm 0.59^{\mathrm{b} 2}$ & $9.83 \pm 0.46^{3}$ & $8.38 \pm 0.60^{\mathrm{al}}$ & $7.57 \pm 0.64^{\mathrm{al}}$ \\
\hline \multirow{3}{*}{$0.5 \% \mathrm{LF}$} & 1. & $11.02 \pm 0.65^{\mathrm{al}}$ & $10.63 \pm 0.88^{1}$ & $7.75 \pm 0.46^{\mathrm{c} 3}$ & $6.09 \pm 0.58^{c 3}$ \\
\hline & 10. & $10.78 \pm 0.55^{\mathrm{b} 2}$ & $10.21 \pm 0.29^{2}$ & $8.16 \pm 0.82^{\mathrm{bl}}$ & $7.27 \pm 0.41^{\mathrm{b} 2}$ \\
\hline & 20. & $10.54 \pm 0.48^{\mathrm{b} 2}$ & $9.85 \pm 0.43^{3}$ & $8.34 \pm 0.77^{\mathrm{al}}$ & $7.63 \pm 0.83^{\mathrm{al}}$ \\
\hline \multirow{3}{*}{$1 \% \mathrm{LF}$} & 1. & $10.73 \pm 0.34^{\mathrm{bl}}$ & $10.44 \pm 0.81^{1}$ & $7.82 \pm 0.46^{c 3}$ & $6.02 \pm 0.77^{c 2}$ \\
\hline & 10. & $10.25 \pm 0.74^{c^{2}}$ & $10.11 \pm 0.68^{2}$ & $8.12 \pm 0.66^{\mathrm{b} 2}$ & $7.35 \pm 0.62^{\mathrm{bl}}$ \\
\hline & 20. & $10.25 \pm 0.55^{\mathrm{c} 2}$ & $9.82 \pm 0.52^{3}$ & $8.36 \pm 0.38^{\mathrm{al}}$ & $7.55 \pm 0.29^{\mathrm{al}}$ \\
\hline
\end{tabular}

${ }^{a-c / 1-3}$ Means in the same column followed by different letters were significantly different according to fiber and different numbers were significantly different according to storage period $(\mathrm{p}<0.01)$

AF: Apple fiber, LF: Lemon fiber 
Lactococcus spp. counts were between 9.79$10.88 \log \mathrm{cfu} \mathrm{mL}^{-1}$ during storage time (Fig 1). Addition of DF didn't influenced Lactococcus spp. counts of kefir ( $p>0.05)$. Montanuci et al. (2012) also reported that addition of inulin did not affect Lactococcus spp. counts of kefir. The samples fortified with AF had slightly higher Lactococcus spp. counts than the other samples. Lactococcus spp. counts increased as the DF increased up to at a rate of $0.5 \%$, then it reduced. During storage Lactococcus spp. counts reduced about a $0.8 \log$ cycle due to the high acidity of kefir. Garrote et al. (1998) and Magra et al. (2012) reported that the lactococci in kefir were sensitive to low $\mathrm{pH}$.

Addition of DF, fiber type and fiber rate did not change the Leuconostoc spp. and the yeast (Table 3) of kefir samples $(\mathrm{p}>0.05)$. Similar results were reported by Ertekin and Guzel-Seydim (2010) and Montanuci et al. (2012) for inulin added kefirs. Leuconostoc spp. and yeast counts increased about $1.5 \log$ cycle during the storage period. Montanuci et al. (2012) reported that yeast and Leuconostoc counts increased during storage due to the metabolism of lactose by Leuconostoc.

\section{Sensory evaluations}

Addition of DF had significant effect on the sensory characteristics (Figure 1$)$ of kefirs $(p<0.01)$. $0.5 \% \mathrm{AF}$ added kefirs had the highest sensory scores and $1 \%$ LF added kefirs had the lowest sensory scores. While Ertekin and Guzel-Seydim (2010) and Glibowski and Kowalska (2012) reported that addition of inulin had no effect on sensory properties of kefir, Tratnik et al. (2006) and Glibowski and Zielinska (2015) had reported that addition of inulin had negative effect on the taste of kefir. In this study, DF addition positively influenced taste and aroma, consistency and general acceptability scores up to at a rate of $0.5 \%$, because of better mouth thickness and pleasant aroma of them. The higher fiber concentration (1\%) caused the lower sensory scores. It could be related to the insoluble parts of the AF and LFs. The all sensory scores of the samples increased during storage for up to 10 days, and then decreased. This could be associated with development of acidity and decreases in aroma compounds (such as acetaldehyde) contents of the samples during storage.

\section{Conclusions}

The enrichment of kefir with DF is an effective way to enhance physiological aspects of the final product. Addition of DF led to improvement of the physical, microbiological and sensory properties of kefir depending on the rate of DF. Addition of DF up to $0.5 \%$ positively affected viscosity, LAB, Lactococcus spp. counts and sensory properties of kefir. Usage of DF at a rate of $1 \%$ had negatively affected $\mathrm{a}_{\mathrm{w}}$, color (L, a, b), LAB, Lactococcus spp. counts and sensory properties of kefir. Results showed that AF and LF can be used successfully in the production of kefir at a rate of $0.25 \%$ or $0.5 \%$. (a)

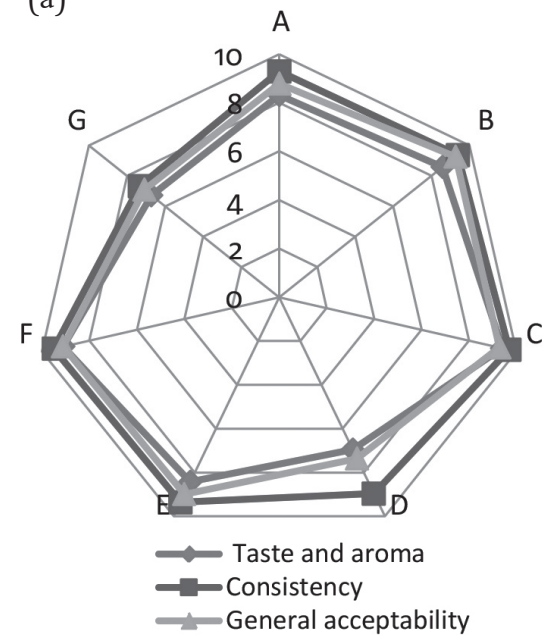

(b)

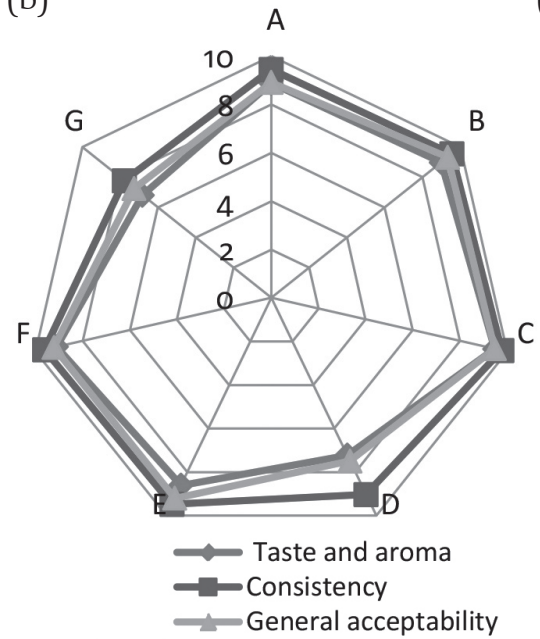

(c)

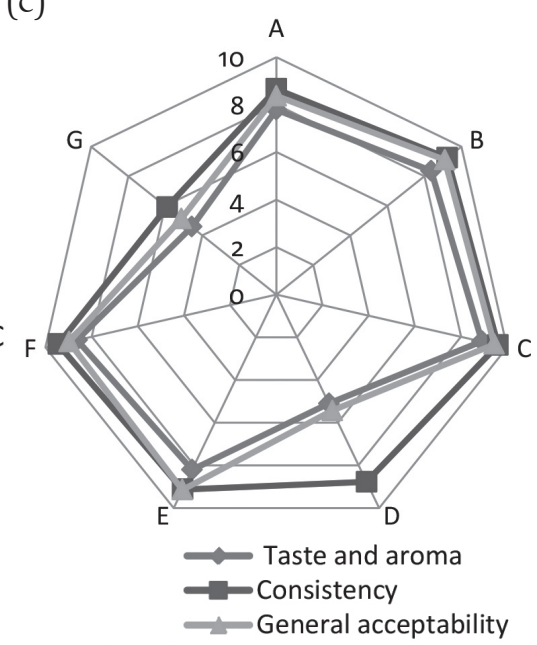

Figure 1. Sensory properties of kefir samples (a) $1^{\text {st }}$ day. (b) $10^{\text {th }}$ day (c) $20^{\text {th }}$ days of storage period 


\section{Obogaćivanje kefira vlaknima jabuke i limuna}

\section{Sažetak}

Istražen je utjecaj dodatka vlakana jabuke i limuna na neka svojstva kefira. U tu svrhu proizvedeno je pet različitih kefira (A je kontrolni, B, C, D, E, F i G: sadrže $0,25 \%$ jabučnih vlakana, $0,5 \%$ jabučnih vlakana, $1 \%$ jabučnih vlakana, 0,25 \% limunskih vlakana, 0,5\% limunskih vlakana i $1 \%$ limunskih vlakana), koji su bili pohranjeni 20 dana na $4 \pm 1{ }^{\circ} \mathrm{C}$. $\mathrm{pH}$, titriracijska kiselost, suha tvar, aktivnost vode, kapacitet zadržavanja vode, viskoznost, L, a i b vrijednosti, senzorska analiza, ukupni broj bakterija mliječne kiseline, Lactococcus spp., Leuconostoc spp. i broj kvasaca u kefiru određeni su 1., 10. i 20. dana skladištenja. Dobiveni rezultati upućuju na to da dodatak vlakana jabuke i limuna poboljšava reološka, mikrobiološka i senzorska svojstva kefira $(\mathrm{p}<0,01)$, te da se vlakna jabuke i limuna mogu koristiti za proizvodnju kefira do udjela od 0,25 \% ili 0,5\%.

\section{Ključne riječi: kefir, jabučna vlakna, limunska vlakna, kvaliteta}

\section{References}

1. Agama-Acevedo, E., Islas-Hernandez, J.J., PachecoVargas, G., Osorio-Diaz, P., Bello-Perez, L.A. (2012): Starch digestibility and glycemic index of cookies partially substituted with unripe banana flour. LWT - Food Science and Technology 46, 177-182. https://doi.org/10.1016/j.lwt.2011.10.010

2. Akin, M.B., Akin, M.S., Kirmaci, Z. (2007): Effects of inulin and sugar levels on the viability of yogurt and probiotic bacteria and the physical and sensory characteristics in probiotic ice cream. Food Chemistry 104 (1), 93-99. https://doi.org/10.1016/j.foodchem.2006.11.030

3. Akin, M.S. (2005): Effects of inulin and different sugar levels on viability of probiotic bacteria and the physical and sensory characteristics of probiotic fermented icecream. Milchwissenschaft 60 (3), 297-301.

4. AOAC. (1990): Official methods of analysis (15th ed.). Arlington: A. Press.

5. Ayhan, K. (2000): Gidalarda Bulunan Mikroorganizmalar. In: Gıda Mikrobiyolojisi ve Uygulamalar. Ankara: Sim Matbaac1lik Ltd. Sti.

6. Bodyfelt, F.W., Tobias, J., Trout, G.M. (1988): The Sensory Evaluation of Dairy Products. New York.
7. Brennan, C.S., Cleary, L.J. (2005): The potential use of cereal $(1-3,1-4)-\beta-D$-glucans as functional food ingredients. Journal of Cereal Science 42, 1-13. https://doi.org/10.1016/j.jcs.2005.01.002

8. Chifiriuc, M.C., Cioaca, A.B., Lazar, V. (2011): In vitro assay of the antimicrobial activity of kefir against bacterial and fungal strains. Anaerobe 17, 433-435. https://doi.org/10.1016/j.anaerobe.2011.04.020

9. De Lima, A.C.S., Soares, D.J., Da Silva L.M.R., De Figueiredo R.W., De Sousa P.H.M., De Abreu, E. (2014): In vitro bioaccessibility of copper, iron, zinc and antioxidant compounds of whole cashew apple juice and cashew apple fiber (Anacardium occidentale L.) following simulated gastrointestinal digestion. Food Chemistry 161, 142-147. https://doi.org/10.1016/j.foodchem.2014.03.123

10. Dello Staffolo, M, Bertola, N, Martino, M., Bevilaqcua, A. (2004): Influence of dietary fiber addition on sensory and rheological properties of yogurt. International Dairy Journal 14, 263-268. https://doi.org/10.1016/j.idairyj.2003.08.004

11. Dervisoglu, M., Yazici, F. (2006): The effect of citrus fiber on the physical, chemical and sensory properties of ice cream. Food Science and Technology International 12, 159-164. https://doi.org/10.1177/1082013206064005

12. Düzgüneş, O., Kesici, T., Kavuncu, O., Gürbüz, F. (1987): Arastırma ve Deneme Metotları (IstatistikMetotları II). Ankara.

13. Elleuch, M., Bedigian, D., Roiseux, O., Besbes, S., Blecker, C., Attia, H. (2011): Dietary fiber and fiberrich by-products of food processing: Characterisation, technological functionality and commercial applications: A review. Food Chemistry 124 (2), 411-421. https://doi.org/10.1016/j.foodchem.2010.06.077

14. Ertekin, B., Guzel-Seydim, Z.B. (2010): Effect of fat replacers on kefir quality. Journal of the Science of Food and Agriculture 90, 543-548. https://doi.org/10.1002/jsfa.3855

15. Ferliarslan, İ. (2012): Farkli Oranlarda Yulaf Lifi ve İnülin İlavesinin Kayısıl l Probiyotik Fermente Süt İceceğinin Bazı Özelliklerine Etkileri. Harran Üniversitesi Fen bilimleri Enstitüsü, G1da Mühendisliği ABD Yüksek Lisans Tezi (Ms thesis), Sanlıurfa, Turkey.

16. Figuerola, F., Hurtado, M.L., Estevez, A.M., Chiffelle, I., Asenjo, F. (2005): Fiber concentrates from apple pomace and citrus peel as potential fiber sources for food enrichment. Food Chemistry 91, 395-401. https://doi.org/10.1016/j.foodchem.2004.04.036

17. Fu, J.T., Chang, Y.H., Shiau, S.Y. (2015): Rheological, antioxidative and sensory properties of dough and Mantou (steamed bread) enriched with lemon fiber. LWT - Food Science and Technology 61, 56-62. https://doi.org/10.1016/j.lwt.2014.11.034

18. Garcia Fontan, M., Martinez S., Franco, I., Carballo, J. (2006): Microbiological and chemical changes during the manufacture of Kefir made from cows' milk, using a commercial starter culture. International Dairy Journal 16 (7), 762-767. https://doi.org/10.1016/j.idairyj.2005.07.004

19. Garrote, G.L., Abraham, A.G., De Antoni, G.L. (2001): Chemical and microbiological characterization of kefir grains. Journal of Dairy Research 68 (4), 639-652. https://doi.org/10.1017/S0022029901005210 
20. Glibowski, P., Kowalska, A. (2012): Rheological, texture and sensory properties of kefir with high performance and native inulin. Journal of Food Engineering 111, 299-304. https://doi.org/10.1016/j.jfoodeng.2012.02.019

21. Glibowski, P., Zielinska, E. (2015): Physicochemical and sensory properties of kefir containing inulin and oligofructose. International Journal of Dairy Technology 68, 602-607. https://doi.org/10.1111/1471-0307.12234

22. Gonzalez-Tomas, L., Coll-Marques, J., Costell, E. (2008): Viscoelasticity of inulin- starchbased dairy systems. Influence of inulin average chain length. Food Hydrocolloids 22, 1372-1380. https://doi.org/10.1016/j.foodhyd.2007.08.001

23. Gronnevik, H., Falstad, M., Narvhus, J.A. (2011): Microbiological and chemical properties of Norwegian kefir during storage. International Dairy Journal 21, 601-606. https://doi.org/10.1016/j.idairyj.2011.01.001

24. Grzegorczyk, A., Wszołek, M. (2010): The transformation of nitrogenous relationship in the cow's milk and goat's milk during fermentation with part of different cultures the kefir (in Polish). Acta Scientarum Polonarum Biotechnologia 9, 11-22.

25. Gularte, M.A., Hera, E., Gomez, M., Rosell, C.M. (2012): Effect of different fibers on batter and gluten-free layer cake properties. LWTFood Science and Technology 48, 209-214. https://doi.org/10.1016/j.lwt.2012.03.015

26. Güler-Akin, M.B., Akin, M.S. (2007): Effects of cysteine and different incubation temperatures on the microflora, chemical composition and sensory characteristics of bio-yogurt made from goat's milk. Food Chemistry 100 (2), 788-793. https://doi.org/10.1016/j.foodchem.2005.10.038

27. Guzeler, N., Akın, M.B., Karaca, O.B., Yasar, K. (2010): Farkl Oranda Kayısl Lifi Kullanıminın Probiyotik Yağsız Yoğurdun Özellikleri Üzerine Etkisi. TÜBİTAK Projesi (No: 107O421) Sonuç Raporu, Adana.

28. Guzel-Seydim, Z., Wyffels, J.T., Seydim, A. (2005): Turkish kefir and kefir grains: microbial enumeration and electron microscopic observation. International Journal of Dairy Technology 58: 25-29. https://doi.org/10.1111/j.1471-0307.2005.00177.x

29. Lawrence, A.J. (1968): The Determination of Lactose in Milk Products. The Austarlian Journal of Dairy Technology 23, 103.

30. Macagnan, T.F., Roberto, B.S., De Moura, F.A., Bizzani, M., Da Silva, L.P. (2015): Biological properties of apple pomas, orange bassage and passion fruit peel as alternative sources of dietary fiber. Bioactive Carbohydrates and Dietary Fiber 6 (1), 1-6. https://doi.org/10.1016/j.bcdf.2015.04.001

31. Magra, T.I., Antoniou, K.D., Psomas, E.I. (2012): Effect of milk fat, kéfir grain inoculum and storage time on the flow properties and microbiological characteristics of kefir. Journal of Texture Studies 43, 299-308. https://doi.org/10.1111/j.1745-4603.2011.00343.x

32. Marin, F.R., Soler-Rivas, C., Benavente-Garcia, O., Castillo, J., Pérez-Alvarez, J.A. (2007): By-products from different citrus processed as a source of customized functional fibers. Food Chemistry 100, 736-741. https://doi.org/10.1016/j.foodchem.2005.04.040
33. Montanuci, F.D., Pimentel, T.C., Garcia, S., Prudencio, S.H. (2012): Effect of starter culture and inulin addition on microbial viability, texture, and chemical characteristics of whole or skim milk kefir. Ciência e Tecnologia de Alimentos 32, 850-861. https://doi.org/10.1590/s0101-20612012005000119

34. Mudgil, D., Barak, S. (2013): Composition, properties and health benefits of indigestible carbohydrate polymers as dietary fiber: a review. International Journal of Biological Macromolecules 61, 1-6. https://doi.org/10.1016/j.ijbiomac.2013.06.044

35. Mudgil, D., Barak, S., Khatkar, B.S. (2016): Development of functional yoghurt via soluble fiber fortification utilizing enzymatically hydrolyzed guar gum. Food Bioscience 14, 28-33. https://doi.org/10.1016/j.fbio.2016.02.003

36. Paquet, E., Bedard, A., Lemieux, S., Turgeona, S.L. (2014): Effects of apple juice-based beverages enriched with dietary fibers and xanthan gum on the glycemic response and appetite sensations in healthy men. Bioactive Carbohydrates and Dietary Fiber 4, 39-47. https://doi.org/10.1016/j.bcdf.2014.06.008

37. Rosi, J., Rossi, J. (1978): The kefir microorganisms: the lactic acid bacteria. Scienza e Tecnica Lattiero-Casearia 29, 291-305.

38. Sendra, E., Fayos, P., Lario, Y., Fernandez-Lopez, J., Sayas-Barbera, E., Perez-Alvarez, J.A. (2008): Incorporation of citrus fibers in fermented milk containing probiotic bacteria. Food Microbiology 25, 13-21. https://doi.org/10.1016/j.fm.2007.09.003

39. Soukoulis, C., Lebesi, D., Tzia, C. (2009): Enrichment of ice cream with dietary fiber: Effects on rheological properties, ice crystallisation and glass transition phenomena. Food Chemistry 115, 665-671. https://doi.org/10.1016/j.foodchem.2008.12.070

40. T.S.E. (1994): Çig Süt Standardı. T.S. 1330, Türk Standartları Enstitüsü, Ankara.

41. Toba, T., Arihara, K., Adachi, S. (1987): Comparative study of polysaccharides from kefir grains, an encapsulated homofermentative Lactobacillus species and Lactobacillus kefir. Milchwissenschaft 42, 565-568.

42. Tratnik, Lj., Bozanic, R., Herceg, Z., Drglic, I. (2006): The quality of plain and supplemented kefir from goat's and cow's milk. International Journal of Dairy Technology 59, 40-46. https://doi.org/10.1111/j.1471-0307.2006.00236.x

43. Tungland, B.C., Meyer, D. (2002): Nondigestible oligoand polysaccharides (dietary fiber): their physiology and role in human health and food. Comprehensive Reviews in Food Science and Food Safety 1, 73-92. https://doi.org/10.1111/j.1541-4337.2002.tb00009.x

44. Van Wyk, J. (2001): The inhibitory activity and sensory properties of kefir, targeting the low-income African consumer market. MSc. thesis. University of Stellenbosch, Stellenbosch, South Africa.

45. Wszolek, M., Tamime, A.Y., Muirs, D.D., Barclay, M.N.I. (2001): Properties of kefir made in Scotland and Poland using bovine, caprine and ovine milk with different starter cultures. Lebensmittel Wissenschaft und Technologie 34, 251-261. https://doi.org/10.1006/fstl.2001.0773 